\title{
Does The Type Of Nephrectomy Affect Oncologic Outcomes İn Pathological Stage pTt1 Renal Cell Carcinoma With High Fuhrman Grade?
}

\section{Yüksek Fuhrman Dereceli Patolojik pT1 Evre Renal Hücreli Karsinomda Nefrektomi Şekli Onkolojik Sonuçları Etkiler Mi?}

\author{
İsmail Selvi ${ }^{1}$, Erdem Öztürk² \\ ${ }^{1}$ Karabük Üniversitesi Eğitim ve Araştırma Hastanesi, Üroloji Kliniği, Karabük, Türkiye \\ ${ }^{2}$ SBÜ Dr. Abdurrahman Yurtaslan Ankara Onkoloji Eğitim ve Araştırma Hastanesi, Üroloji Kliniği, Ankara, \\ Türkiye
}

\section{ÖZET}

GİRIŞ ve AMAÇ: Klinik evre I renal hücreli karsinom(RHK) olgularında, günümüzde öncelikli olarak önerilen cerrahi teknik parsiyel nefrektomidir (PN). Ancak tümöre ait olumsuz patolojik özellikler varlığında, daha kötü bir prognoz gözlenebilmektedir. Çalışmadaki amacımız, patolojik tanısı yüksek Fuhrman dereceli(derece 3-4) pT1 evre RHK gelen olgularda, cerrahi teknik olarak parsiyel veya radikal nefrektomi (RN) uygulanmış olmasının, postoperatif dönemde lokal nüks, uzak metastaz gelişimi ve kansere özgü sağkalıma etkisinin değerlendirilmesidir.

YÖNTEM ve GEREÇLER: Ocak 2009-Temmuz 2016 tarihleri arasında, PN veRN yapılan hastalar içerisinden, patolojik tanısı yüksek Fuhrman dereceli pT1 evre RHK gelen, verilerine tam olarak ulaşılabilen 66 hasta çalışmaya dahil edildi. Hastaların demografik verileri, histolojik tümör tipi, tümörün Fuhrman derecesi, nefrektomi sonrası sağkalım, lokal nüks ve metastaz verileri kaydedilerek, hastalar RN (Grup I) ve PN(Grup II) uygulananlar şeklinde iki gruba ayrıldı.

BULGULAR: Hastaların ortalama yaşı $57.67 \pm 10.23$ olup,ortanca $57(6-102)$ aylık takip süresi boyunca $6(\% 9.1)$ hastada lokal nüks, $8(\% 12.1)$ hastada uzak metastaz, $8(\% 12.1)$ hastada kansere bağlı ölüm gerçekleşmiştir.PN grubunda daha yüksek lokal nüks oranı $(\% 11.1, \mathrm{p}=0.532)$, uzak metastaz oranı $(\% 18.9, \mathrm{p}=0.630)$ ve kansere özgü sağkalım süresi (94.16 ay, $p=0.560)$ saptanırken; öngörülen nükssüz sağkalım süresi (89.46 ay, $p=0.433)$ ve metastazsız sağkalım süresi (84.94 ay, $\mathrm{p}=0.617$ ) daha düşük bulundu. Ancak gruplar arasında anlamlı bir fark izlenmedi. Çok değişkenli analizde, hipertansiyon lokal nüksü; Fuhrman derece 4, kadın cinsiyet, VKI>27 olması uzak metastazı; tahmini glomerüler filtrasyon hızı $<90$ olması ise kansere özgü sağkalımı etkileyen bağımsız prediktif faktörler olarak saptandı.

TARTIŞMA ve SONUÇ: Yüksek Fuhrman dereceli pT1 evre RHK olgularında cerrahi yöntem olarak PN veya RN uygulanmış olmasının, izlemde onkolojik sonuçları anlamlı olarak değiştirmediğini saptadık. Bu nedenle tümör boyutu ve lokalizasyonu uygun olan olgularda, nefron koruyucu teknik olan PN'yi kullanmak daha uygun gözükmektedir.

Anahtar Kelimeler: Onkolojik sonuçlar, parsiyel nefrektomi, renal hücreli karsinom, T1 evre, Yüksek Fuhrman derecesi

\section{ABSTRACT}

INTRODUCTION: In clinical stage I renal cell carcinoma (RCC), partial nephrectomy (PN) is actual recommended surgical technique. However, poor pathological tumor features have more negative prognosis. We aimed to evaluate the effects of performing partial or radical nephrectomy $(\mathrm{RN})$ on local recurrence, distant metastasis and cancer-specific survival in stage pT1 RCC with high Fuhrman grade.

METHODS: Data of patients who underwent PN or RN due to pathological stage pT1 RCC with high Fuhrman grade, between January 2009 and July 2016 were retrospectively evaluated. 66 of them whose datas were fully accessible, were included to study. Demographic datas, histological tumor types, Fuhrman grading, local 
recurrence, distant metastasis and survival rates after nephrectomy were recorded. The patients were divided into two groups as RN (Group I) and PN (Group II).

RESULTS: Mean age of patients was 57.67 \pm 10.23 . Among them, $6(9.1 \%)$ patients had local recurrence, $8(12.1 \%)$ had distant metastasis and $8(12.1 \%)$ had cancer related death. Group II had higher local recurrence rate $(11.1 \%, \mathrm{p}=0.532)$, distant metastasis rate $(18.9 \%, \mathrm{p}=0.630)$, cancer-specific survival (94.16 months, $\mathrm{p}=0.560)$; lower predicted recurrence-free survival ( 89.46 months, $\mathrm{p}=0.433$ ) and metastasis-free survival ( 84.94 months, $\mathrm{p}=0.617$ ). But there were no significantly difference. In multivariate analysis, hypertension for local recurrence; Fuhrman grade 4, female gender, BMI $>27$ for distant metastasis, and estimated glomerular filtration rate $<90$ for cancer-specific survival were independent predictive factors.

DISCUSSION and CONCLUSION: We found that PN or RN did not significantly alter the oncologic outcomes in follow-up of patients with high Fuhrman grade, stage pT1 RCC. For this reason, it is more appropriate to use nephron sparing technique.

Keywords: High Fuhrman grade, oncologic outcomes, partial nephrectomy, renal cell carcinoma, T1 stage

\section{GíRIŞ}

Renal hücreli karsinomun (RHK), günümüzde rastlantısal olarak saptanma siklığ görüntüleme yöntemlerinin yaygın kullanımı sonucu giderek artmaktadır (1). Çoğunlukla küçük boyutta, lokalize evrede (evre I-II) saptanan RHK, tüm kanserlerin \%2-3'ünü oluşturmakta olup, altıncı ve yedinci dekatta görülme oranı daha fazladır (2). Özellikle lokalize evre tümörlerde nefrektomi çoğu kez küratif tedaviyi sağlasa da, uzun dönem takiplerde lokal nüks veya uzak metastaz gelişme oranlarının $\quad \% \quad 20-40$ olduğu bilinmektedir (3).

Son yıllarda nefron koruyucu yaklaşımın postoperatif dönemde hem kardiyovasküler hem de genel sağkalım açısından öneminin anlaşılması sonucu, özellikle klinik evre I tümörlerde parsiyel nefrektomi (PN) tekniği giderek popüler hale gelmiştir. Parsiyel veya radikal nefrektomi (RN) kararını vermede en önemli yol gösterici bulgu tümör çapı ve konfigürasyonudur (4). Bu evrede PN'nin hem fonksiyonel nefron yapısını koruduğu hem de RN olgularıyla benzer sağkalım sonuçlarına sahip olduğu bilinse de, literatürde yüksek Fuhrman derecesine sahip pT1 evre olgularda iki cerrahi yöntemin onkolojik sonuçlarını birbiriyle karşılaştıran bir çalışma bulunmamaktadır (5). Çalışmamızda patolojik tanıs1 yüksek Fuhrman dereceli (derece 3-4) pT1 evre RHK gelen olgularda, cerrahi teknik olarak PN veya RN uygulanmış olmasının, postoperatif dönemde lokal nüks, uzak metastaz gelişimi ve kansere özgü sağkalıma etkisini değerlendirmeyi amaçladık.

\section{MATERYAL ve METOT}

Kliniğimizde Ocak 2009-Temmuz 2016 tarihleri arasında, klinik evre I RHK tanısıyla parsiyel veya radikal nefrektomi yapılan, patolojik tanıs1 yüksek Fuhrman dereceli (derece 3 ve 4), pT1 evre RHK gelen, verilerine tam olarak ulaşılabilen 66 hasta retrospektif olarak değerlendirilerek çalışmaya dahil edildi. Hastaların demografik verileri, sigara kullanma durumu, diyabet, hipertansiyon varlığı, vücut kitle indeksi (VKİ), histolojik tümör tipi, tümörün Fuhrman derecesi, nekroz varlığı, sarkomatoid komponent varlığı, tümör tarafi, lokalizasyonu, boyutu, operasyon şekli, nefrektomi sonras1 takip süresi, lokal nüks, metastaz ve sağkalım oranlar1 kaydedildi. Preoperatif kreatinin, cinsiyet yaş ve ırk faktörlerini kullanarak, kısa Modification of Diet in Renal Disease (MDRD) formülü ile hesaplanan tahmini glomerüler filtrasyon hizı (eGFR) hesaplandı. RN uygulanan 30 hasta Grup I, PN uygulanan 36 hasta Grup II olarak isimlendirilerek, hastalar randomizasyon yapilmadan iki gruba ayrıldı. Gruplar onkolojik sonuçlar açısından karşılaştırıld1.

\section{Cerrahi Yöntem}

$\mathrm{RN}$, böbreğin mevcut tümöral kitle ile birlikte, etraf organ ve dokulardan serbestlendikten sonra renal arter, ven ve varsa aksesuar dalları da bağlanarak Gerota fasiası ile birlikte çıkarılmasıdır. PN ise, tümörün yerleştiği böbrek polüne ait segmental damarların bulunarak bağlanmasının ardından veya ana renal arterde gecici bir klempleme işlemi ile kanama kontrolü sağlandıktan sonra, tümör etrafında en fazla $5 \mathrm{~mm}$ 'lik sağlam parankim dokusunu da içerecek şekilde enükleasyon veya rezeksiyon ile tümörlü yapının 
çıkarılması ve kalan sağlam böbrek parankiminin korunmasıdır. Her iki cerrahi yöntem de günümüzde açık, laparoskopik ve robotik yaklaşımlarla yapılmakla birlikte, çalışmaya dahil ettiğimiz 66 hastada belirtilen tarihlerde tüm cerrahiler açık yaklaşımla yapılmıştır.

\section{İstatistiksel Analiz}

İki grup arasındaki farklılıkları karşılaştırmak için, Kolmogorov-Smirnov ve Shapiro-Wilk testleri ile normalite durumu değerlendirildikten sonra, kategorik değișkenler için Pearson ki-kare analizi; sürekli değişkenler için Independent sample t test veya Mann-Whitney U testi kullanıld1. Sağkalım analizleri için Kaplan-Meier, buna etkili olan değişkenleri belirlemede Cox regresyon analizi kullanıldı. Analizler IBM SPSS Statistics 21 (IBM, Armonk, NY USA) yazılımı kullanılarak yapıldı. $\mathrm{p}<0.05$ değerleri istatistiksel olarak anlamlı kabul edildi.

\section{BULGULAR}

Çalışmaya dahil edilen 66 hastanın ortalama yaş1 $57.67 \pm 10.23$ olup, hastaların 44 (\%66.7)'ü erkek, 22 (\%33.3)'si kadındı. Ortanca 57 (6102) aylık takip süresi boyunca $6(\% 9.1)$ hastada lokal nüks, 8 (\%12.1) hastada uzak metastaz, 8 (\%12.1) hastada kansere bağl1 ölüm gerçekleşmiştir. Uzak metastazlar 4 hastada akciğere, 2 hastada kemiğe, 2 hastada karaciğere olmuştur. Hastaların demografik, patolojik, klinik verileri ve onkolojik sonuçları Tablo 1'de görülmektedir.

PN grubunda daha yüksek lokal nüks oranı (\%11.1 vs. $\% 6.6, \mathrm{p}=0.532)$ ve uzak metastaz oran $1 \% 18.9$ vs. $\% 10, p=0.630)$ gözlenmekle beraber, anlamlı bir farklılık saptanmadi. PN grubunda öngörülen nükssüz sağkalım süresi ( 89.46 vs. 93.53 ay, $p=0.433$ ) ve metastazsız sağkalım süresi (84.94 vs. 90.72 ay, $\mathrm{p}=0.617$ ) daha düşük olmakla beraber, istatistiksel olarak anlamlı değildi (Şekil 1 ve 2). Öngörülen kansere özgü sağkalım süresi ise, PN grubunda daha fazla bulunsa da (94.16 vs. 88.43 ay, $\mathrm{p}=0.560$ ) iki grup arasinda yine anlamlı bir fark izlenmedi (Şekil 3).



Şekil 1: İki grup için öngörülen nükssüz sağkalım süreleri

Tek değişkenli analizde, eGFR ve hipertansiyon varlığının hem lokal nüks, hem uzak metastaz gelişimi ve hem de kansere özgü sağkalımı öngören bağımsız prediktif faktörler olduğu bulunurken; Fuhrman derece 4 varlığ1 derece 3'e göre uzak metastaz gelişimi ve kansere özgü sağkalımı daha anlamlı olarak etkilemektedir. Çok değişkenli analizde ise, hipertansiyon lokal nüksü; Fuhrman derece 4, kadın cinsiyet, VKI>27 olması uzak metastazi; eGFR $<90$ olması ise kansere özgü sağkalımı etkileyen bağımsız prediktif faktörler olarak saptandı (Tablo 2). Bu bulgulara göre cerrahi yöntem olarak PN veya $\mathrm{RN}$ uygulanmas1 onkolojik sonuçları anlamlı olarak etkileyen bir faktör değildir.



Şekil 2: İki grup için öngörülen metastazsız sağkalım süreleri 


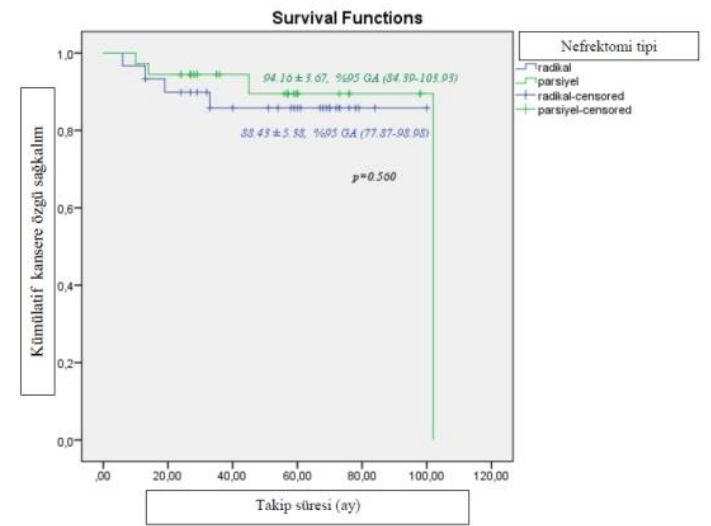

Şekil 3: İki grup için öngörülen kansere özgü sağkalım süreleri

Tablo 1: Hastaların demografik, patolojik, klinik verileri ve onkolojik sonuçları

\begin{tabular}{|c|c|c|c|c|}
\hline Parametreler & $\begin{array}{l}\text { Grup I } \\
(\mathbf{n : 3 0})\end{array}$ & $\begin{array}{c}\text { Grup II } \\
(\mathbf{n : 3 6})\end{array}$ & $\begin{array}{l}\text { Toplam } \\
\text { (n:66) }\end{array}$ & p değeri \\
\hline $\begin{array}{c}\text { Yaş, } \\
\text { ortalama } \pm \text { standart sapma }\end{array}$ & $59.40 \pm 10.0$ & $56.22 \pm 10.16$ & $57.67 \pm 10.23$ & +0.211 \\
\hline $\begin{array}{c}\text { Cinsiyet }(\mathrm{n}, \%) \\
\text { erkek } \\
\text { kadın }\end{array}$ & $\begin{array}{l}19(63.3) \\
11(36.7)\end{array}$ & $\begin{array}{l}25(69.4) \\
11(30.6)\end{array}$ & $\begin{array}{l}44(66.7) \\
22(33.3)\end{array}$ & +0.600 \\
\hline $\begin{array}{c}\text { VKI }\left(\mathrm{kg} / \mathrm{m}^{2}\right) \\
(\text { median, 25.-75. persentil) }\end{array}$ & $\begin{array}{c}24.45 \\
(23.57-27.72) \\
\end{array}$ & $\begin{array}{c}25.05 \\
(23.50-27.87) \\
\end{array}$ & $\begin{array}{c}24.6 \\
(23.50-27.82) \\
\end{array}$ & $\S 0.752$ \\
\hline $\begin{array}{c}\text { Sigara içme } \\
\text { evet } \\
\text { hayır }\end{array}$ & $\begin{array}{l}14(46.7) \\
16(53.3)\end{array}$ & $\begin{array}{l}19(52.8) \\
17(47.2)\end{array}$ & $\begin{array}{l}33(50) \\
33(50)\end{array}$ & +0.621 \\
\hline $\begin{array}{l}\text { Hipertansiyon } \\
\text { var } \\
\text { yok } \\
\end{array}$ & $\begin{array}{l}12(40) \\
18(60)\end{array}$ & $\begin{array}{l}11(30.5) \\
25(69.5) \\
\end{array}$ & $\begin{array}{l}23(34.8) \\
43(65.2) \\
\end{array}$ & +0.423 \\
\hline $\begin{array}{c}\text { Diyabet } \\
\text { var } \\
\text { yok }\end{array}$ & $\begin{array}{c}7(23.3) \\
23(76.7)\end{array}$ & $\begin{array}{l}12(33.3) \\
24(66.7)\end{array}$ & $\begin{array}{l}19(28.8) \\
47(71.2)\end{array}$ & +0.372 \\
\hline $\begin{array}{c}\text { Tümör tarafi } \\
\text { sağ } \\
\text { sol }\end{array}$ & $\begin{array}{l}18(60) \\
12(40)\end{array}$ & $\begin{array}{l}16(44.4) \\
20(55.6)\end{array}$ & $\begin{array}{l}34(51.5) \\
32(48.5)\end{array}$ & +0.208 \\
\hline $\begin{array}{c}\text { Tümör lokalizasyonu } \\
\text { üst pol } \\
\text { orta pol } \\
\text { alt pol } \\
\text { hiler } \\
\end{array}$ & $\begin{array}{c}8(26.7) \\
5(16.7) \\
7(23.3) \\
10(33.3) \\
\end{array}$ & $\begin{array}{c}13(36.1) \\
8(22.2) \\
11(30.6) \\
4(11.1) \\
\end{array}$ & $\begin{array}{l}21(31.8) \\
13(19.7) \\
18(27.3) \\
14(21.2) \\
\end{array}$ & +0.184 \\
\hline $\begin{array}{c}\text { Patolojik tümör } \\
\text { boyutu }(\mathrm{cm}) \\
\text { (median, 25.-75. persentil) }\end{array}$ & $\begin{array}{c}5.50 \\
(4.87-6.50) \\
\end{array}$ & $\begin{array}{c}3.10 \\
(2.50-4.00) \\
\end{array}$ & $\begin{array}{c}4.20 \\
(3.00-5.50) \\
\end{array}$ & $\S<0.001 *$ \\
\hline $\begin{array}{c}\text { Histolojik alt tip }(\mathrm{n}, \%) \\
\text { Şeffaf hücreli } \\
\text { Papiller } \\
\text { Kromofob } \\
\text { Diğer } \\
\end{array}$ & $\begin{array}{c}23(76.6) \\
3(10) \\
2(6.7) \\
2(6.7) \\
\end{array}$ & $\begin{array}{c}20(55.5) \\
10(27.8) \\
1(2.8) \\
5(13.9) \\
\end{array}$ & $\begin{array}{c}43(65.1) \\
13(19.7) \\
3(4.6) \\
7(10.6) \\
\end{array}$ & $\$ 0.116$ \\
\hline $\begin{array}{c}\text { Fuhrmann derece }(\mathrm{n}, \%) \\
3 \\
4 \\
\end{array}$ & $\begin{array}{c}26(86.7) \\
4(13.3)\end{array}$ & $\begin{array}{c}31(86.1) \\
5(13.9)\end{array}$ & $\begin{array}{l}57(86.3) \\
9(13.7) \\
\end{array}$ & +0.948 \\
\hline $\begin{array}{c}\text { Patolojik evre }(\mathrm{n}, \%) \\
\text { T1a } \\
\text { T1b } \\
\end{array}$ & $\begin{array}{c}4(13.3) \\
26(86.7)\end{array}$ & $\begin{array}{c}27(75) \\
9(25) \\
\end{array}$ & $\begin{array}{l}31(46.9) \\
35(53.1)\end{array}$ & $t<0.001 *$ \\
\hline
\end{tabular}




\begin{tabular}{|c|c|c|c|c|}
\hline $\begin{array}{c}\text { Nekroz varlığı }(\mathrm{n}, \%) \\
\text { var } \\
\text { yok } \\
\end{array}$ & $\begin{array}{l}11(36.7) \\
19(63.3)\end{array}$ & $\begin{array}{l}15(41.7) \\
21(58.3) \\
\end{array}$ & $\begin{array}{l}30(45.5) \\
36(54.5)\end{array}$ & +0.679 \\
\hline $\begin{array}{c}\text { Sarkomatoid komponent } \\
\text { varlığ }(\mathrm{n}, \%) \\
\text { var } \\
\text { yok } \\
\end{array}$ & $\begin{array}{c}8(26.7) \\
22(73.3) \\
\end{array}$ & $\begin{array}{l}15(41.7) \\
21(58.3)\end{array}$ & $\begin{array}{l}23(34.8) \\
43(65.2)\end{array}$ & $\$ 0.203$ \\
\hline $\begin{array}{c}\text { eGFR, } \\
\text { ortalama } \pm \text { standart sapma }\end{array}$ & $86.39 \pm 17.99$ & $86.07 \pm 14.53$ & $86.21 \pm 16.07$ & +0.937 \\
\hline $\begin{array}{c}\text { Takip süreleri, } \\
\text { median (min-max) ay }\end{array}$ & $\begin{array}{r}59.5 \\
(6-100) \\
\end{array}$ & $\begin{array}{c}50.5 \\
(10-102) \\
\end{array}$ & $\begin{array}{c}57 \\
(6-102) \\
\end{array}$ & $\S 0.221$ \\
\hline Lokal nüks oranı $(\mathrm{n}, \%)$ & $2(6.6)$ & $4(11.1)$ & $6(9.1)$ & +0.532 \\
\hline Uzak metastaz oranı $(\mathrm{n}, \%)$ & $3(10)$ & $5(18.9)$ & $8(12.1)$ & +0.630 \\
\hline $\begin{array}{l}\text { Kansere özgü sağkalım } \\
\text { oranı }(\%)\end{array}$ & 86.7 & 88.9 & 87.9 & +0.783 \\
\hline
\end{tabular}

$\dagger$ Independent sample t test † Ki-kare $\S$ Mann-Whitney U

$* \mathrm{p}<0.05$ (Gruplar arasında anlamlı fark var)

Tablo 2: Lokal nüks gelişimi, uzak metastaz gelişimi ve kansere özgü sağkalımı öngören faktörler

\begin{tabular}{|c|c|c|c|c|c|c|c|c|}
\hline \multirow[b]{3}{*}{ Lokal Nüks Gelişimi } & \multicolumn{4}{|c|}{ Tek Değişkenli Model } & \multicolumn{4}{|c|}{ Çok Değişkenli İndirgenmiş Model } \\
\hline & \multirow{2}{*}{ HR } & \multicolumn{2}{|c|}{$\% 95 \mathrm{GA}$} & \multirow{2}{*}{ p } & \multirow{2}{*}{$H R$} & \multicolumn{2}{|c|}{$\% 95$ GA } & \multirow{2}{*}{ p } \\
\hline & & Alt & Üst & & & Alt & Üst & \\
\hline eGFR<90 & 0,906 & 0,828 & 0,991 & 0.031 & & & & \\
\hline \multirow[t]{3}{*}{ Hipertansiyon } & 1,079 & 1,029 & 1,131 & 0.002 & 1,126 & 1,037 & 1,222 & 0.005 \\
\hline & \multicolumn{4}{|c|}{ Tek Değişkenli Model } & \multicolumn{4}{|c|}{ Çok Değişkenli İndirgenmiş Model } \\
\hline & \multirow{2}{*}{ HR } & \multicolumn{2}{|c|}{$\% 95 \mathrm{GA}$} & \multirow{2}{*}{ p } & \multirow{2}{*}{$H R$} & \multicolumn{2}{|c|}{$\% 95 \mathrm{GA}$} & \multirow{2}{*}{$\mathrm{p}$} \\
\hline Metastaz Gelişimi & & Alt & Üst & & & Alt & Üst & \\
\hline Fuhrman derecesi 4 & 7,404 & 1,850 & 29,638 & 0.005 & 10,537 & 2,241 & 49,541 & 0.003 \\
\hline Nekroz varlığı & 4,730 & 0,954 & 23,451 & 0.047 & & & & \\
\hline Sarkomatoid komponent & 6,021 & 1,213 & 29,896 & 0.028 & & & & \\
\hline Kadın cinsiyet & 5,703 & 1,146 & 28,375 & 0.033 & 7,434 & 1,129 & 48,948 & 0.037 \\
\hline Diyabet varlığı & 4,489 & 1,072 & 18,796 & 0.040 & & & & \\
\hline$V K K \mid>27$ & 1,747 & 1,282 & 2,381 & $<0.001$ & 1,747 & 1,282 & 2,381 & $<0.001$ \\
\hline Hipertansiyon & 1,079 & 1,029 & 1,131 & 0.002 & & & & \\
\hline eGFR<90 & 0,903 & 0,835 & 0,976 & 0.010 & & & & \\
\hline
\end{tabular}

\begin{tabular}{|c|c|c|c|c|c|c|c|c|}
\hline \multirow[b]{3}{*}{ Kansere Özgü Sağkalım } & \multicolumn{4}{|c|}{ Tek Değişkenli Model } & \multicolumn{4}{|c|}{ Çok Değişkenli İndirgenmiş Model } \\
\hline & \multirow{2}{*}{ HR } & \multicolumn{2}{|c|}{$\% 95 \mathrm{GA}$} & \multirow{2}{*}{$p$} & \multirow{2}{*}{$\mathrm{HR}$} & \multicolumn{2}{|c|}{$\% 95 \mathrm{GA}$} & \multirow{2}{*}{$p$} \\
\hline & & Alt & Üst & & & Alt & Üst & \\
\hline Fuhrman derecesi 4 & 4,992 & 1,114 & 22,371 & 0.036 & & & & \\
\hline eGFR $<90$ & 0,896 & 0,822 & 0,977 & 0.013 & 0,896 & 0,822 & 0,977 & 0,002 \\
\hline Hipertansiyon & 1,068 & 1,015 & 1,124 & 0.012 & & & & \\
\hline
\end{tabular}

Cox Regresyon Analizi 


\section{TARTIŞMA}

RHK'da prognozu etkileyen etkenler arasında tümöre ait anatomik ve histolojik faktörler (tümör-nod-metastaz (TNM) evresi, Fuhrman derecesi, histolojik tümör tipi, tümör boyutu, nekroz varlığı, sarkomatoid komponent varlığı vs.) ve hastaya ait faktörler (genel sağllk durumu, semptomlar, klinik bulgular, laboratuvar bulguları, moleküler faktörler) bulunmaktadır. Bunlar arasında patolojik TNM evresi en önemli etken olarak belirtilmiş olup (6), patolojik evre T1a ve T1b için bildirilen 10 yıllık kansere özgü sağkalım oranları sırasıyla \%90-95 ve \%80-85'tir (7).

Patolojik $\mathrm{T}$ evresine bakılmaksızın sadece Fuhrman derecesi incelendiğinde, derece I, II, III, IV için 5 yıllık sağkalım oranlar1 sirasiyla $\% 64, \% 34, \% 31$ ve $\% 10$ olarak bildirilmiştir. Bu derecelemenin lokalize T1-T2 hastalıkta da önemini koruyan prognostik bir faktör olduğu bilinmektedir (8). Çok merkezli 5009 hastalık bir seride, median 105 aylık izlemde, nefrektomiden 5 y1l sonra lokal nüks görülme oranları T1a ve T1b için sirasıly \%17.1 ve \%23.9 olarak gözlenirken, bu nükslerin çoğu Fuhrman derece 3-4 olgularda saptanmıştır (9).

Klinik T1 evre RHK'larda son y1llarda nefron koruyucu yaklaşımlar popüler hale gelmiştir. Ancak T1 evredeki hangi olguların PN'ye daha uygun olabileceği hususunda araştırmalar devam etmektedir. Bu konuda en önemli yol gösterici bulgu tümör çapı ve konfigürasyonudur. $\mathrm{Bu}$ amaçla geliştirilmiş olan nomogramlardan günümüzde en yaygın olarak kullanılanı RENAL nefrometri skorudur (RNS). Tümör çap1, tümörün ekzofitik / endofitik oluşu, tümörün toplama sistemine veya sinüse yakınlığı, anterior / posterior yerleşimi, polar hatlara göre lokasyonu ve hiler yerleşimli tümörün ana böbrek arterine veya venine olan yakınlığı göz önüne alınarak yapılan RNS' na göre 4-6, 7-9, 10-12 aras1 değerler sırasıyla düşük, orta ve yüksek riskli grup olarak yorumlanmaktadır (4). Yüksek riskli gruptaki $\mathrm{T} 1$ evre tümörde cerrahi esnasında kanama, inkomplet enükleasyon, cerrahi sınır pozitifliği riski, postoperatif takipte lokal nüks gelişme oranının daha fazla olabileceği öngörülmekte ve bu olgularda RN tercihi daha çok öne çıkmaktadır (10).
RHK olgularında PN kararını vermede RNS'nin kullanım yaygınlığı 2007 öncesinde \%36 düzeyinde iken, bu oran 2010-2012 yılları arasında \%73'e kadar çıkmıştır. Bu süreçte tümör boyutu ve anatomik lokalizasyonun patolojik evre up-staging ve onkolojik sağkalım sonuçları açısından önemi daha iyi anlaşıldığından, orta ve yüksek RNS'ye sahip hastalara uygulanan PN oranlarında giderek bir azalma gözlenmiştir (11).

Klinik T1 evre RHK'da PN yapılan 830 olgunun (pT1, pT2, pT3 oranları sirasiyla $\% 86.8, \% 1.6, \% 11.6)$ takibinde, yüksek pT evresi, yüksek Fuhrman derecesi, pozitif cerrahi sınır varlığı ve yüksek RNS'nin lokal nüks oranlarını artırarak hastalıksız sağkalımı anlamlı olarak azalttı̆̆ ; pT evresi ve Fuhrman derecesinin metastaz gelişimi açısından bağımsız prediktif faktör olduğu gözlendi. 5 yıllık hastalıksız sağkalım ve genel sağkalım oranlar1 sirasiyla $\% 91$ ve $\% 94$ saptanırken; lokal nüks gelişimine kadar geçen median süre 13 ay, metastaza kadar geçen median süre 22 ay olarak gözlendi (12).

Robotik PN yapılan klinik T1 evredeki 1096 RHK hastasının incelendiği başka bir çalışmada, yüksek RNS (özellikle de artan tümör çapı ve hiler lokalizasyon) patolojik evre up-staging açısından anlamlı bulundu. Daha kötü tümör karakteristiklerini içeren pT3a evre hastaların iki yıllık izleminde nükssüz sağkalım oran1 \%91.8 iken, pT1-pT2 için \%99.2 bulundu (13). pT3a evre 43 hastadan takiplerinde lokal nüks görülen iki hastanın da yüksek Fuhrman derecesine (derece 3) sahip olduğu saptandı.

Mouracade ve ark. 1042 olguluk serilerinde, klinik T1 evre RHK nedeniyle PN yapılan hastaların \%10.8 'inde pT3a evreye up-staging saptadılar. Yüksek RNS, yüksek Fuhrman derecesi ve erkek cinsiyette olmak pT3a evresine up-staging'i artıran faktörler olarak gösterildi. pT3a evre hastalarda pT1 evre ile kıyaslandığında, nükssüz sağkalım oranının anlamlı olarak daha düşük olduğu gözlendi (\%78.5 vs. \%94.6) (14).

Brookman ve ark. nın 5009 hastalık çok merkezli çalışmasında, RHK olgularında nükslerin yaklaşık \%10-20'sinin, nefrektomi sonras1 5 y1ldan daha uzun sürede geliştiği gözlenmiştir. 105 aylık takipte geç nüksü 
öngören bağımsız risk faktörleri; lenfovasküler invazyon, yüksek (3-4) Fuhrman derecesi, patolojik evrenin $>\mathrm{T} 1$ olmasıdır. Nükslerin \%40'1 T1 evrede saptanmış olup yüksek Fuhrman derecesinde daha fazladır. Uzak nüks oranları, RN yapılan grupta PN'li hastalara göre anlamlı olarak daha fazla görülmüştür. Kansere bağlı mortaliteyi öngören faktörler arasında ise, bu üç faktöre ek olarak artan yaş ve kadın cinsiyette olmak gösterilmiştir (9).

Böbrek biyopsisi sonucu yüksek (3-4)

Fuhrman derecesi saptanan, non-metastatik evredeki 76 olgunun 35'ine PN, 41'ine RN uygulanan güncel bir çalışmada, PN uygulanan olgularda daha fazla oranda hastaliksız sağkalım ve kansere özgü sağkalım olduğu gözlenmiştir. Her ne kadar yüksek Fuhrman derecesinin onkolojik sonuçları kötüleştirdiği bilinse de, bu hastalarda dahi uygulanacak PN'nin gözlenebilecek lokal nüks ve kansere bağlı mortalite oranlarını artırmadığ gösterilmiştir (5). Ancak bu çalışmada pT1 evre olgulara ait alt grup analizi yapılmadan, non-metastatik T1-T4 evredeki tüm hastalar incelenmiştir. Ayrıca günümüzde bazı özel endikasyonlar haricinde RHK'da böbrek biyopsisi rutin önerilen bir yöntem olmayıp, görüntüleme bulgularına göre yapılan klinik evrelemeye göre nefrektomi kararı verilmektedir.

Çalışmamızda yüksek Fuhrman derecesine sahip pT1a ve pT1b hastalarda median 64 (6-102) aylık izlemde gözlenen lokal nüks oranları sirasiyla $\% 9.67$ ve $\% 8.57$, uzak metastaz oranlar1 \%6.45 ve \%17.14, kansere özgü sağkalım oranları \%93.55 ve \%82.86 olup onkolojik sonuçlarımız mevcut literatür verileriyle uyumludur. Tüm pT1 evre hastalar incelendiğinde, PN uygulanmış grupta lokal nüks oranı (\%11.1) ve uzak metastaz oran1 (\%18.9) RN uygulananlardan daha yüksek olsa da anlamlı bir fark gözleyemedik. Yine PN grubunda öngörülen nükssüz sağkalım süresi (89.46 ay) ve metastazsız sağkalım süresi (84.94 ay) daha düşük, kansere özgü sağkalım süresi (94.16 ay) daha fazla olmakla beraber, iki yöntem arasında anlamlı bir fark saptayamadık. Literatür incelendiğinde, RN uygulanmış hastalarda Brookman ve ark. lokal nüks oranını, Goldberg ve ark. ise lokal nüks ve kansere bağlı mortaliteyi anlamlı olarak daha fazla saptamış olsalar da bu çalışmalarda hastaların tamamı
pT1 evre değildi $(5,9)$. Olgular klinik evre I RHK nedeniyle opere edilmiş olup patoloji sonucuna göre pT2, pT3 ve pT4 evreye upgrading olan hastaları da içermekteydi. Bu nedenle mevcut çalışmamızın diğer çalışmalardan ayrılan yanı, pT1 evre, yüksek Fuhrman dereceli RHK olgularında RN ve PN sonrası izlem sonuçlarının incelenmesidir.

PN'de korunan nefron miktarının daha fazla olmasının ileriki yıllarda kronik böbrek hastalığına $(\mathrm{KBH})$ gidişi azaltacağı bilinmektedir. Üçüncü derece $\mathrm{KBH}$ olarak kabul edilen eGFR $45-60 \mathrm{ml} / \mathrm{dk} / 1.73 \mathrm{~m}^{2}$ değeri, RN sonras1 olguların \%65'inde, PN sonras1 \%20'inde görülmektedir. Dördüncü ve beşinci derece KBH $\left(\mathrm{eGFR}<45 \mathrm{ml} / \mathrm{dk} / 1.73 \quad \mathrm{~m}^{2}\right)$ gözlenme oranı ise $\mathrm{RN}$ sonras1 \%36, PN sonras1 \%5'tir (15). Nefrektomi sonras1 eGFR'de oluşan azalma kardiyovasküler hastalık ve ölüm oranlarında artışa, genel sağkalımda azalmaya yol açabilmektedir $(16,17)$. Ahmedov ve ark. preoperatif hesaplanan eGFR değeri daha düşük hastalarda, nükssüz sağkalımın ve kansere özgü sağkalımın olumsuz olarak etkilendiğini göstermiştir (18). Çalışmamızda hastaların hepsinde preoperatif eGFR $>60 \mathrm{ml} / \mathrm{dk} / 1.73 \mathrm{~m}^{2}$ olup, iki grup arasinda ortalama eGFR değerleri $\quad(86.39 \pm 17.99$ vs. $86.07 \pm 14.53)$ açısından anlamlı fark saptanmadi. Ancak tek değişkenli analizde, preoperatif eGFR düzeyinin $<90$ olmasının lokal nüks ve metastaz görülme oranlarını etkilediğini gözlerken; tek ve çok değişkenli analizlerde, eGFR<90 olmasının kansere özgü sağkalım açısından bağımsız prediktif faktör olduğunu saptadik.

Çalışmamızda nefrektomi patolojisi pT1 evre RHK olan yüksek Fuhrman dereceli hastalarda cerrahi yöntem olarak PN veya $\mathrm{RN}$ uygulanmasının onkolojik sonuçları anlamlı olarak etkilemediğini, bu özel alt grupta asıl önemli etkenlerin hipertansiyon varlığı ve eGFR olduğunu gözlemledik.

Çalışmamızın retrospektif oluşu, düşük hasta popülasyonu içermesi, bu nedenle randomizasyon oluşturulamaması, izlem sonuçlarının tek merkeze ait olması başlıca kısitlayıc1 etkenlerdir.

Sonuç olarak pT1 evre RHK olgularında, yüksek Fuhrman derecesi sağkalım sonuçlarını anlamlı olarak etkilemediğinden, rutin olarak nefrektomi 
öncesi biyopsi yapıp çıkacak Fuhrman derecesine göre PN veya RN kararı vermek çok gerekli gözükmemektedir. Bu nedenle güncel uygulamalarla da uyumlu olarak, biyopsi yapmak yerine, tümör boyutu ve lokalizasyonu uygun olan hastalarda nefron koruyucu PN uygulamasina öncelik vermenin daha uygun olduğunu düşünmekteyiz. Yine de çok merkezli, geniş hasta sayılı, prospektif, randomize, daha uzun izlem sonuçlarının olduğu başka çalışmalarla, sonuçların desteklenmesi ve konunun aydınlatılması gerekmektedir.

\section{Çıkar Çatışması: Yok}

\section{REFERANSLAR}

1. Rendon RA, Kapoor A, Breau R, et al. Surgical management of renal cell carcinoma: Canadian Kidney Cancer Forum Consensus. Can Urol Assoc J 2014;8:398-412.

2. Lipworth L, Tarone RE, McLaughlin JK. The epidemiology of renal cell carcinoma. J Urol 2006;176:2353-2358.

3. Rodriguez-Covarrubias F, Gomez-Alvarado MO, Sotomayor $\mathrm{M}$, et al. Time to Recurrence after Nephrectomy as a Predictor of Cancer-Specific Survival in Localized Clear-Cell Renal Cell Carcinoma. Urol Int. 2011; 86: 47-52.

4. Tobert CM, Kahnoski RJ, Thompson DE et al.RENAL nephrometry score predicts surgery type independent of individual surgeon's use of nephronsparing surgery.Urology. 2012;80(1):157-61.

5. Goldberg H, Chandrasekar T, Klaassen Z et al. Does Partial Nephrectomy for Biopsy Proven Fuhrman Grade 3/4 Renal Cell Carcinoma Confer Worse Outcomes Compared to Radical Nephrectomy? J Urol Supp 2018;199(4):e631.

6. Ljungberg $\mathrm{B}$, Albiges $\mathrm{L}$, Bensalah $\mathrm{K}$ et al. EAU guidelines on renal cell carcinoma: 2018 update. http://uroweb.org/guideline/renal-cell-carcinoma/.

7. Patard JJ, Dorey FJ, Cindolo L, et al. Symptoms as well as tumor size provide prognostic information on patients with localized renal tumors. J Urol 2004; 172:2167-2171.
8. Fuhrman SA, Lasky LC, Limas C. Prognostic significance of morphologic parameters in renal cell carcinoma. Am J Surg Pathol 1982; 6:655-663.

9. Brookman-May S, May M, Shariat SF et al. Features associated with recurrence beyond 5 years after nephrectomy and nephron-sparing surgery for renal cell carcinoma: development and internal validation of a risk model (PRELANE score) to predict late recurrence based on a large multicenter database (CORONA/SATURN Project).Eur Urol. 2013;64(3):472-7.

10. Boylu U, Güzel R, Turan $T$ et al. Predictive value of R.E.N.A.L. nephrometry score in robotic assisted partial nephrectomy. Turkish Journal of Urology 2011;37(2):81-85.

11. Lane BR, Golan S, Eggener $S$ et al.Differential use of partial nephrectomy for intermediate and high complexity tumors may explain variability in reported utilization rates.J Urol. 2013;189(6):204753.

12. Mouracade $P$, Kara $O$, Maurice MJ et al. Patterns and Predictors of Recurrence after Partial Nephrectomy for Kidney Tumors. J Urol 2017;197(6):1403-1409.

13. Gorin MA, Ball MW, Pierorazio PM et al. Outcomes and predictors of clinical $\mathrm{T} 1$ to pathological T3a tumor up-staging after robotic partial nephrectomy: a multi-institutional analysis. J Urol. 2013;190(5):1907-11.

14. Mouracade $P$, Kara $O$, Dagenais $J$ et al. Perioperative morbidity, oncological outcomes and predictors of pT3a upstaging for patients undergoing partial nephrectomy. World J Urol. 2017;35(9):1425-1433.

15. Russo P, Huang W. The medical and oncological rationale for partial nephrectomy for the treatment of T1 renal cortical tumors. Urol Clin North Am 2008; 35:635-643.

16. Go AS, Chertow GM, Fan D, et al. Chronic kidney disease and the risks of death, cardiovascular events, and hospitalization. N Engl J Med 2004; 351:1296.

17. Kambara $T$, Tanimoto $R$, Araki $M$, et al.Renal Function after Nephrectomy Influences the Risk of Cardiovascular Events.Acta Med Okayama. 2018;72(3):241-247.

18. Ahmedov V, Kızılay F, Cüreklibatır İ.Prognostic Significance of Body Mass Index and Other Tumor and Patient Characteristics in Non-Metastatic Renal Cell Carcinoma. Urol J. 2018;15(3):96-103. 